Marquette University

e-Publications@Marquette

Economics Faculty Research and Publications

Economics, Department of

$1-1-2007$

\title{
Effective Foreign Aid, Economic Integration and Subsidiarity: Lessons from Europe
}

\author{
Abdur Chowdhury \\ Marquette University, abdur.chowdhury@marquette.edu \\ Paolo Garonna \\ United Nations Economic Commission for Europe, in Geneva
}

Published version. Effective Foreign Aid, Economic Integration and Subsidiarity: Lessons from Europe. The paper was presented at the international conference "Winds of Change", organized by CASE - Center for Social and Economic Research and CASE Ukraine in Kiev on March 23- 24, 2007. Publisher Link. (C) 2007 CASE - Center for Social and Economic Research, Warsaw. Used with permission. 


\title{
St udia i Analizy studies \& Analyses
}

\author{
Centrum Analiz \\ Spoleczno - Ekonomicznych
}

Center for Social

and Economic Research

346

Abdur Chowdhury, Paolo Garonna

Effective Foreign Aid, Economic Integration and Subsidiarity: Lessons from Europe 
Materials published here have a working paper character. They can be subject to further publication. The views and opinions expressed here reflect the author(s) point of view and not necessarily those of CASE.

The paper was presented at the international conference "Winds of Change", organized by CASE - Center for Social and Economic Research and CASE Ukraine in Kiev on March 2324, 2007.

\section{Winds of Change}

\section{The Impact of Globalization on Europe and Asia}

Key words: foreign aid, economic integration, subsidiarity.

(C) CASE - Center for Social and Economic Research, Warsaw 2007

Graphic Design: Agnieszka Natalia Bury

ISSN 1506-1701, ISBN 978-83-7178-436-1 EAN 9788371784361

Publisher:

CASE - Center for Social and Economic Research

12 Sienkiewicza, 00-010 Warsaw, Poland

tel.: (48 22) 62266 27, 82861 33, fax: (48 22) 8286069

e-mail: case@case.com.pl

http://www.case.com.pl/ 


\section{Contents}

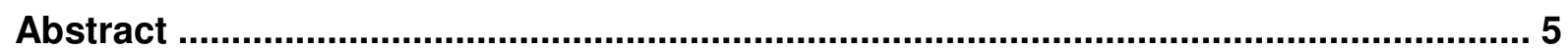

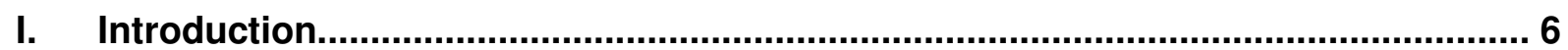

II. Trends in Development Assistance: a Controversial Picture ................................... 8

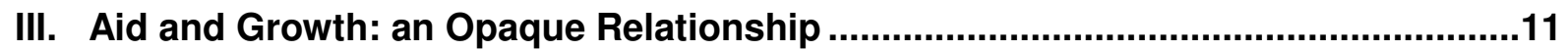

IV. The Conditions under which Foreign Aid Promotes Economic Growth .................12

V. The Focus on What Works and What does not Work ...........................................14

VI. The European Experience: What Are the Main Lessons ........................................15

VII. The Secret of European Success: towards a New Synthesis .................................16

VIII. Economic Integration and Subsidiarity - The Conditions of Aid Effectiveness.....16

IX. Conclusions ...............................................................................................21

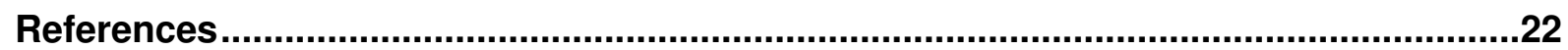


Abdur Chowdhury has a Masters and a Ph.D. in Economics from the University of Kentucky in the United States. Since September 2003, he has been working as the Director of the Economic Analysis Division and the Technical Cooperation Unit of the United Nations Economic Commission for Europe in Geneva. Prior to joining the United Nations, he has worked for fourteen years as Professor of Economics, Marquette University, USA. He also held positions as a Faculty member at Johns Hopkins University and Bentley College, USA; and also worked as a Senior Researcher at the Central Bank of Finland and Senior Fulbright Scholar in Thailand. He has conducted research on a variety of global economic, political and social issues and has published extensively in international professional journals, newspapers and other media outlets. His most recent research deals with financial integration in the transition economies.

Paolo Garonna is currently Deputy Executive Secretary of the United Nations Economic Commission for Europe, in Geneva. He is also full professor of Economics on leave from the Faculty of Political Science of the University LUISS G. Carli in Rome. From 2003 to 2005, Mr. Garonna was Chief Economist and Director of Research at Confindustria, the main employers' organisation in Italy. In the 1990's, Mr. Garonna was Director General of the National Statistical Institute of Italy (ISTAT). He also worked at the OECD in Paris as Deputy Director for Education Employment Labour and Social Affairs. He joined the United Nations in 1999 as Director of the Statistical Division of the United Nations ECE. In August 2001 he was appointed Deputy Executive Secretary of the UNECE, and then from November 2001 to March 2002, and from August 2005 to February 2006, was Officer-in-Charge Executive Secretary of the same organisation.

He had his first degree at the University of Rome (Law degree), and undertook graduate studies in economics at the University of Denver (USA), as Fulbright scholar, and at the University of Cambridge (UK). He was an economic advisor to the Italian Government (Prime Minister Office, Labour Minister, Finance Minister and Treasury), and internationally (e.g. for the 11th French Plan, and for the European Commission in Brussels). He acted as high-level consultant for international organisations in Europe and worldwide. He had his academic career at the Faculty of Statistics of the University of Padua, in Italy. He was visiting professor in several Universities in Europe (e.g. the University of Paris). 


\section{Abstract}

The paper shows that the question that is relevant for the debate on the efficacy of development assistance is not so much as an issue of how much, but rather for what. In view of the growing awareness of ODA's inefficiency in achieving intended aims, this paper proposes an alternative approach to development assistance policies - economic integration and subsidiarity provides the conditions necessary for ODA to produce higher rates of economic growth on a sustainable basis. Europe is an excellent case in point, in this context. Europe has in the last decades experienced a number of success stories in moving out of poverty and onto sustainable economic growth. The secret of success has been the push towards economic integration, and the adoption of economic reforms at the local, national, and regional level conducive to economic growth. The recipient countries of development assistance have much to learn from the European experience. 


\section{Introduction}

More than fifteen years after the end of the Cold War, the world seems poised to fall into another deep seated polarisation: the one between the developed and the developing world. The fracture is not only economic and social, linked to the persisting gaps in standards of living and opportunities, but above all political, with the risk of becoming "ideological" and providing support to radicalism extremism and civilisation clashes. We see this new bipolarism at play in the stalled Doha negotiations, in the aborted reforms of global institutions, in the confrontations concerning human rights, and even in the different approaches to fighting terrorism and building peace and security.

Development assistance is at the heart of this new polarisation. The growing distrust and antagonism in the developing world against the rich countries is fed by the widespread persuasion that the developed countries are not doing what they should do, and are not even living up to what they promised to do: sharing opportunities with the less fortunate, supporting development and fighting poverty. This call into question shared values and builds frustration, a sense of betrayal, sometimes disillusion and despair.

The public opinion in the developed world is also reacting in an "ideological" way: development assistance is nothing else than a way to finance corruption and waste, to instigate a culture of dependency, to buttress undemocratic regimes and unsustainable economic policies. It is not surprising then that, faced with hard public expenditures choices in the context of ever tighter budgets, governments give low priority to ODA and public awareness and support for ODA eclipse. Moreover the poor of the world do not vote, and in particular they do not vote in advanced industrial democracies.

These polarised views find an echo in the scientific literature, which itself is becoming polarised between the ODA preachers and the ODA bashers. However, there is a growing number of contributions, which do not take side in the political controversy and explore possible "third ways", dwelling in particular on the conditions under which ODA can produce its desired outcomes.

This paper intends to propose another third way approach to development assistance policies, based on a synthesis view, and a new view, of the factors that explain the effectiveness of ODA. The conditions under which ODA produces higher rates of economic growth on a sustainable basis can be summed up in two basic factors: economic integration and subsidiarity. ODA is growth inducing only to the extent that (i). development assistance stimulates and supports the integration of national and local economies at the international level, both globally and regionally, (ii) determines institutional reforms and sound economic 
policies at the appropriate level of government (global, regional, national and local), and (iii) leaves the private sector to play its fundamental role. This approach is proposed based on a review of the literature and by drawing on the experience of European economies, particularly in the last two decades.

First, we will dispose of a few ideological positions that are particularly unhelpful in bridging the perception gaps between the developed and the developing countries. We argue that speculating on a presumed shift of values in the western world is unwarranted: there is no ethical collapse away from generosity solidarity or justice towards unfettered profit making and self-interest promotion. If we add to the ODA expenditures, the expenditure for peace keeping and humanitarian intervention, which has been growing at an unprecedented way, the picture of the donors countries' commitments, changes significantly: it is not so much a question of how much, but rather for what.

We also show that the distortions argument is well founded grounded in theory and practical experience: it is not a question of right wing versus left wing, pro-development against anti-development, conservative versus progressive thinking. It is a basic fact to be reckoned with.

An analogy can be drawn with what took place in the 1970's and 1980's with the fiscal crisis of the welfare state, which was first blamed on a conservative attack (Thatcher and Reagan) against the acquis of social progress of the preceding decades, and then came to be acknowledged as a necessary adjustment to the changing conditions of the economy and society. Likewise, ODA is not simply attacked to-day by external critics, but it is being eroded from within by the growing awareness of its inefficiency in achieving intended aims, and the rather restrictive conditions under which it has produced and it can produce its desired impact.

We then show that there are several cases where it can be proved that ODA has been very effective in lifting countries out of poverty onto a path of sustainable growth. Europe is an excellent case in point, in this context. Europe has in the last decades experienced an extraordinary number of success stories in moving out of poverty and backwardness, and onto development and sustainable economic growth. Reference can be made to the case of Ireland, Portugal and Greece, and more recently that of Bulgaria and Rumania, and other new EU member countries. How has Europe achieved such an extraordinary performance? The secret of success has been the push towards economic integration, and the adoption of economic reforms at national, local and European level conducive to sustainable growth.

Reflecting on the European experience and applying it to other contexts, we identify the main factors linking ODA to economic reforms and through them to successful growth performance. The various channels through which ODA affects the integration of markets 
and the reform of policies are then identified and discussed, such as the acceleration of the transfer of knowledge, the support provided to those who lose out because of economic reforms, and the aid for trade measures.

In conclusion ODA is a proxy for economic reforms and policies aimed at promoting and supporting bold economic reforms and the transfer of governance responsibility between the different levels of governance institutions and policies.

The paper is organised as follows. Section II shows the recent trend in various types of aid and peacekeeping expenditures. Section III discusses the relationship between foreign aid and economic growth while Section IV enumerates the conditions which affect the effectiveness of foreign aid. Section $V$ shows what type of assistance work and what doesn't. Sections VI and VII shares the lessons that could be learnt from the European experience. Finally, Section VIII presents the main thesis of the paper showing how economic integration and subsidiarity could ensure aid effectiveness.

\section{Trends in Development Assistance: a Controversial Picture}

Official Development Assistance: the betrayal of donors?

Are rich countries withdrawing from their commitments? Is the gap in ODA undermining the achievement of the policy commitments of the international community, notably the Millennium Development Goals?

These are some of the questions that are being raised in the development circles. In order to set the stage for understanding the implications of these questions, we begin with a look at the current trend in Official Development Assistance (ODA) and other forms of aid flowing from the donor to the recipient countries.

According to the estimates of the UN Millennium Project, achieving the MDGs requires an increase of aid flows to at least $\$ 150$ billion per year. This would be also consistent with the commitments the donors have made under the Monterrey Consensus of the International Conference on Financing for Development to work towards reaching the UN target of 0.7 percent of GNI.

Following the promises made by the EU and by the G8 at its summit in Gleneagles to increase aid by some $\$ 50$ billion by 2010 , the official development assistance (ODA) from the countries of the OECD to developing countries rose to a record high of $\$ 106$ billion in 2005. This total represents 0.33 percent of the Development Assistance Committee (DAC) 
countries' combine GNI, up from 0.26 percent in 2004 . In order to achieve the target ODA levels, the donors will have to keep increasing aid by an average of over 8 percent per year, a rate comparable to the 2005 surge of 8.7 percent in real terms. This means that for most DAC countries, ODA will have to rise at a rate above that of total government expenditure, year after year, which is a challenge at a time when OECD countries' budgets are under considerable pressure.

Charts 1 and 2 report the ODA from the major OECD donors during 1990-2005. In 2005, 22 rich countries ran development programs, sending more than $\$ 100$ billion in development aid overseas. In dollar terms, this was fairly high -- up from a low of $\$ 48$ million in 1997, but still less as a percentage of rich-country GDP than the levels of the late Cold War period. The money went to about 180 countries. Seven of them received over $\$ 1$ billion: China and India, drawing most of their aid from Japan, were at the top; the others were Indonesia, Egypt, Serbia, Mozambique and Russia. Top recipients of U.S. aid are usually countries of high security concern, including Israel, Egypt, Pakistan, Jordan, Colombia, and Russia in recent years. Most aid from Japan, Korea, Australia, and New Zealand, by contrast, goes to neighbouring Asian and Pacific island nations. Europe's recipients are mixed: Greece's \$200 million goes mainly to Balkan-peninsula neighbours such as Macedonia, Albania, Bosnia, and Serbia; most of Ireland's \$400 million goes to Uganda, Ethiopia and other low-income countries in Africa. None of this tells us how well donors choose their priorities, or how well recipients use the money. But underlying all such debates is the suggestion that there really isn't very much foreign aid. The $\$ 106$ billion for 2005 , high by historical standards, was less than 1.0 percent of the $\$ 12$ trillion world GDP for low and middle-income countries (excluding India and China). It was about 7 percent of the $\$ 1.5$ trillion in developing-country export earnings (again excluding Chinese and Indian exports, as well as oil sales by Persian Gulf states); and perhaps most striking, probably less than the $\$ 150-\$ 200$ billion in remittances sent home to developing-country families by overseas workers.

Peace-keeping and humanitarian intervention as complement to development aid.

It is well known and widely recognised that without peace and security there can be no development. Conflict is among the major factors affecting poverty and underdevelopment. Another major factor is natural disasters: while they hit both rich and poor countries, they leave a permanent scar in countries and regions where development opportunities are lacking and undermine profoundly efforts made to overcome obstacles and barriers to economic growth and prosperity. A recent example would be the impact of tsunami on a number of Asian countries including, but not limited to, Indonesia, the 
Philippines, Sri Lanka, and Thailand. Therefore it is appropriate to consider the trends in ODA in connection with those in aid and intervention for peace-keeping, and peace-building and for disaster relief and other humanitarian intervention. If we take an integrated approach to development aid, peacekeeping and humanitarian intervention, the picture of trends in assistance related to development changes significantly. Recent years have seen an exponential increase in peacekeeping budget and humanitarian contribution around the world. The budget for United Nations peacekeeping operations from July 2005 to June 2006 is a record $\$ 5$ billion-climbing past the previous peak of $\$ 4.6$ billion in 2004-05. Some 70,000 soldiers, military observers, and police served in 16 peacekeeping missions at the end of 2005. Including international and local civilian staff and volunteers, total personnel came to about 85,000 . The United Nations also maintains 10 smaller "political and peacebuilding" missions, with a mostly civilian staff of 2,349 as of late 2005. The largest of these are in Afghanistan (set up in March 2002), Iraq (August 2003), and Timor-L'este (May 2005). Table 1 and Chart 3 provide time series figures for peacekeeping expenditures and peacekeeping personnel and shows the exponential growth in both expenditures and personnel in recent years.

Humanitarian aid has also seen a significant increase in recent years. According to OCHA estimates, contributions and commitments for humanitarian aid in 2006 exceeded $\$ 7$ billion. Figures for 2006 classified by donors are given in Table 2 while Table 3 shows the aggregate trend in global humanitarian aid during 2000-2006. As Table 3 shows, global humanitarian contribution has increased in every year since 2000 and the magnitude in increase has been more than four fold during this six year period. However, contributions in 2005 following the tsunami disaster increased to more than $\$ 13$ billion from $\$ 4.7$ billion in 2004.

Integrating development aid with aid linked to peace-keeping operations and humanitarian assistance may look politically controversial. One may object that the latter is most often driven by political considerations and strategic foreign policy interests of donor countries. However, this objection does not stand, as also development aid is mostly driven by the strategic interests of donor countries, It suffices to note the strong preference given by countries to tied aid and bilateral arrangements, and the reluctance of donor countries to relinquish control of technical cooperation activities in the multilateral institutions and arrangements. Besides, generosity and altruism should themselves correspond to longer term strategic interests of the developed world in maintaining international peace and security.

We can conclude then that the recent period has seen both a relative stagnation of the resources allocated to development assistance, but at the same time an exponential increase of the resources made available for intervention linked to peace-keeping and 
humanitarian relief. The experience of the tsunami, when under the impression made by the international media, the public opinion mobilised and managed to collect an impressive amount of donations in a short time is instructive of the kind of response that one can have from the citizens of the rich world when a convincing appeal is made to the need for international solidarity and support. The crisis of ODA therefore cannot be simply explained away by ethical considerations, and corrected by more effective campaigning or preaching or political confrontation. A more structural approach is needed, starting from the revisitation of the relationship between development aid and economic growth performance.

\section{Aid and Growth: an Opaque Relationship}

It is generally argued that most foreign aid tries to achieve one or more of four broad economic and development objectives (Radelet, 2006):

i. to stimulate economic growth through building infrastructure, supporting productive sectors or bringing new ideas and technologies,

ii. to strengthen important sectors, such as, education, health, environment or political systems,

iii. to support subsistence consumption of food and other essential commodities, especially during relief operations or humanitarian crises, or

iv. to help stabilize an economy following economic shocks.

Although policy makers have discussed these broader objectives for aid, economic growth has always been the main criterion used to measure aid's effectiveness. However, there is no clear-cut relationship between aid and growth. Some countries that have received large amounts of aid have experienced high economic growth, while others have shown slow or negative growth. Concurrently, some countries that have received very little aid have done very well, while others have not (Radelet 2006).

What can we conclude from the absence of a clear-cut relationship? For some, it implies a failure of aid to achieve its main objectives, while others underplay the lack of high correlation as misleading since other factors affect both aid and growth. Some countries receiving large amounts of aid may face endemic disease or poor geography, or may be emerging from long-standing civil conflict, in which case aid might have a positive impact on growth even if the overall growth performance remains weak (Radelet 2006).. 
Still others conclude that aid works well under certain conditions, but fails in others. Aid might promote economic growth in countries with reasonably good economic policies, but might not do so where corruption and lack of governance is prevalent. In other words, while the overall trend line is important, the variance around the trend and the reasons for that variance should also be taken into account in understanding the true underlying relationships.

\section{The Conditions under which Foreign Aid Promotes Economic Growth}

Following a number of more recent studies (see in particular Radelet 2006), this Section briefly describes the debate on the conditions under which aid works or does not work. Empirical evidence is mixed, with different studies reaching different conclusions depending on the time frame, countries involved, and assumptions underlying the research. Three broad views have emerged to disentangle the complex relationship between aid and growth:

Aid has a positive relationship with growth on average across countries (although not in every country), but with diminishing returns as the volume of aid increases. There are three main channels through which aid promotes growth:

i. Aid augments savings, finances investment, and adds to the capital stock (Sachs et al, 2004).

ii. Aid increases worker productivity through investments in health and education.

iii. Aid promotes the transfer of technology or knowledge from donor to the recipient countries.

Several early studies found a positive relationship between aid and growth (See Levy 1988 and the references therein), but this strand of literature took a significant turn in the mid1990s when researchers began to investigate whether aid might support growth with diminishing returns. A large group of studies that allow for diminishing returns have found a positive relationship (Dalgaard and Hansen 2000, Hansen and Tarp 2000, Lensink and White 2001, Clemens et al 2004).

Aid also could have a positive impact on such sectors as health, education, environment, etc. Perhaps the best documented area is health where aid-supported programs have helped to eradicate a number of diseases (Levine et al, 2004). 
Aid has no effect on growth, and may actually undermine growth

A number of studies (Dowling and Hiemenz 1982, Boone 1994, Rajan and Subramanium 2005) have suggested a variety of reasons as to why aid might not support growth:

i. Aid encourages corruption.

ii. It perpetuates poor economic policies and postpone reform.

iii. Limited absorptive capacity in the recipient country reduces the effectiveness of aid.

iv. Aid reduces both domestic private and public saving.

Using theoretical and empirical evidences, these studies have shown how development assistance leads to distortion and disruption in the domestic economy.

Aid has a conditional relationship with growth, helping to improve growth under certain conditions. This view holds that aid supports growth in some circumstances but not others, and searches for key characteristics associated with the difference. This conditional strand of the literature has three subcategories, with the effectiveness of aid depending on the characteristics of the recipient country, the practices and procedures of the donors, or the type of activity that the aid supports.

Recipient country characteristics.

Isham, Daufmann and Pritchett (1995) showed that World Bank projects had higher rates of returns in countries with stronger civil liberties. Burnside and Dollar (2000) reported that aid accelerated growth only in countries with good policies. Other researchers have proposed different country characteristics that might affect the aid-growth relationship, including export price shocks, climate shocks, the terms of trade, macroeconomic and trade policies, institutional quality, warfare, type of government and location in the tropics (Burnside and Dollar 2004, Collier and Hoeffler 2002, Dalgaard and Tarp 2004, Radelet 2006).

The view that aid works better in countries with sound economic policies and institutions has become the accepted norm among donors, partly based on the research and partly due to development practitioners that believe this to be the case based on their own experience (Radelet 2003).

\section{Donor practices.}

Donor practices strongly influence aid effectiveness. For example, multilateral aid might be more effective than bilateral aid, or untied aid might be more effective than tied aid. 
Sometimes poor monitoring and evaluation system of the donors undermine the effectiveness of their own programs. It can be argued that aid would be more effective if there were greater 'country ownership' or broader 'participation' among government and community groups in recipient countries in setting priorities and designing programs.

\section{Type of aid.}

Different kinds of aid might affect growth in different ways. Emergency and humanitarian aid is likely to be negatively associated with growth, since aid tends to increase sharply at the same time growth falls following an economic shock. In case of aid for health, education, and the environment, aid might only affect growth after a long lag, if at all. Aid for building roads, ports, and other infrastructure or supporting agriculture may have a direct positive affect on growth.

\section{The Focus on What Works and What does not Work}

The literature on the economic growth impact of Foreign Aid is inconclusive. While a lot of progress has been made in identifying the success factors and analysing the negative consequences of possible distortions induced by assistance, no clear-cut answer can be given on a-priori basis on whether and how assistance translates itself in higher growth, income and jobs. Much more work is needed, particularly at the empirical level in providing evidence to test the theoretical arguments, and in understanding success and failure. The case for, and against, development aid leaves still a great deal to be argued and tested. A lot more sound and independent policy analysis is needed to provide a convincing case, and win the support of the experts, and above all the general public in the developed countries on the need for more, and better development aid.

This is an area where international organisations can and should do much more to provide solid indications of what has worked, and what can work. Indicators of performance, benchmarking tools and policy analysis should feed a science-based objective discussion at the intergovernmental level, and with all stakeholders, of how to make aid work for development, and avoid its undesired side effects.

We need to move on beyond superficial and politicised discussions, wall-to-wall confrontations, ideological statements, campaigning and emotional appeals. We need objective measurement and comparable data. The best way to plead for more international solidarity is through rigorous applied policy analysis and informed discussions aimed at drawing lessons from experience and sharing knowledge. 


\section{The European Experience: What Are the Main Lessons}

There are two basic stories concerning the European experience of ODA and economic growth. One is the experience of Europe as a main donor and source of funding to support development in other parts of the world and in its neighbourhood; the other is the support provided by the EU for integrating successive waves of new member countries, and promoting economic reforms in the policies of its members at the community, national and regional levels (Garonna 2006). The two stories have opposite endings: the first story is one of mixed results in line with the evidence on the impact of ODA is all other contexts; the second is the most extraordinary success story of the last 50-60 years. The EU is the main provider of development assistance in the world (See Table 1 and Figures 1 and 2). However, the track record of this considerable financial effort has come under renewed attack from policy analysts. It has been argued that European development assistance is in disarray, lacking political thrust, strategic purpose and institutional support. This has created perverse incentives inhibiting the innovation and boldness that is required to promote sustainable development and democratic governance in poor countries (Santiso, 2002).

If we consider instead the aid provided by the EU to support the economic integration of its member countries, particularly those relatively disadvantaged, or of acceding new members, as in the case of the EU enlargement of the early 2000's, it has to be recognised that these measures have been quite effective in supporting the integration of European economies and in creating the conditions for sustainable development and growth.

We will focus then on the latter assistance policies, to draw lessons of wider applicability. There are several experiences that can be considered emblematic of the European success in supporting economic integration. Here are the main ones:

1. EU enlargement: support for candidate countries.

2. EU regional policies aimed at supporting industrial restructuring, entrepreneurship, innovation and competitiveness;

3. The single market: policies aimed at supporting the elimination of barriers, the adoption of standards, the better regulation of markets so that there can be a level playing field across the whole European economic space;

4. Policies aimed at giving a role to private players, the social partners, the voluntary sector, the research community, opinion makers, etc. including the role of Public Private Partnerships;

5. Policies giving a role to regional and local governments, local communities and stakeholders (devolution); 
6. Policies transferring responsibilities from national governments to the community (European) level, as in the case of trade, and the Euro.

In all these cases, there is evidence that aid and assistance played an important role in stimulating adjustment and translated itself into sustainable economic growth. For example, between 2000 and 2005 public expenditure at the local and regional levels has been increasing annually by 3.6 percent, faster than GDP (1.7\%) and total public expenditures (2.4\%) (Hubner, 2007). As a result, the share of local and regional authorities in public investment increased from 25.4 percent to 26.8 percent. In some countries, such as Spain, Finland and Denmark, this proportion has increased by 10 percentage points over the last decade.

\section{The Secret of European Success: towards a New Synthesis}

Why has European aid been successful in all these cases and relatively unsuccessful in the other cases? There are two common threads that can be seen at work in all cases of success, and that can be spelled out in the argument as the main factors explaining the effectiveness of aid in relation to growth.

1. the fact that aid promotes economic integration, i.e. the elimination of barriers to economic activity, the enlargement of the market and its smooth functioning;

2. the application of the subsidiarity principle, in that aid stimulates more role by private players (business and civil society), devolving responsibility towards the lower level of government, and the transfer of power towards the European level for decisions that are to be taken at that level. Subsidiarity implies "institutional assignment", i.e. taking policy decisions at the level that is appropriate for that decision.

We can now elaborate on these factors, applying them to the wider context.

\section{Economic Integration and Subsidiarity - The Conditions of Aid Effectiveness}

In this section, we will identify a few conditions where aid could promote growth:

\section{Economic integration -}

Global economic integration is not a new phenomenon. Over centuries, integration through trade, factor movements, and communication of economically useful knowledge and 
technology has been on a generally rising trend. Three factors have affected the process of economic integration and are likely to be its driving force in the future. First, improvements in the technology of transportation and communication have reduced the costs of transporting goods, services and factors of production and of communicating economically useful knowledge and technology. Second, individuals and societies have favoured taking advantage of the opportunities provided by declining costs of transportation and communication through increasing economic integration. Third, public policies have significantly influenced the character and pace of economic integration.

Countries need to promote regional economic integration to overcome the constraints of small market size and to reap the full benefits of economic specialization. Since the developing countries tend to export more to distant developed countries than to developing countries, the potential for regional integration among developing countries is tremendous. For example, to promote intraregional trade, countries should continue to reduce tariffs and invest in trade facilitation by simplifying and automating customs procedures, promoting the mutual recognition of norms and standards, and encouraging trade in services. In some cases, regional currency unions can further aid intraregional trade by reducing the cost of exchange rate fluctuations and further deepening economic integration.

A second dimension of economic integration focuses on sharing the high fixed costs of setting up key institutions for development. Universities, research centers, and standards bodies are critical for generating growth, but frequently impossible for small countries to afford. Many small developing countries also require regional institutions to help them overcome the constraints of small markets and population.

Third, the example of the European Union, which speaks with one voice in international negotiations over trade, shows the regional economic cooperation can strengthen the international voice of developing countries. By agreeing on common positions and objectives, small countries can reduce the cost of international negotiations and increase the likelihood of successful outcomes on issues like trade and debt relief.

These priorities require strong institutions to coordinate the alignment of customs procedures, the harmonization of standards, and the development of joint infrastructure. The European Union has been a good example of promoting economic cooperation in Europe.

Foreign aid helps economic integration in at least three ways. First, aid helps to accelerate knowledge sharing among countries. Second, aid helps in allowing poorer countries to participate in setting standards and in convergence of standards. In other words, aid helps to bring a sense of ownership in the developing countries by providing for an inclusive process. Third, aid helps to compensate the losers from economic integration. It helps to soothe the interest groups who resist economic integration the most. 
Providing sizeable financial assistance has historically been of considerable importance in helping persuade countries of the benefits of economic integration. Liberalisation measures under the regional integration of Europe significantly helped to create a favourable economic environment that contributed to growth and welfare of the weaker member states. These policies were combined with substantial economic assistance and helped to shape positive popular perception of integration. The post-war Marshall Plan was instigated in large measure to neutralise the forces moving Western Europe permanently away from multilateral trade and to thereby facilitate global economic recovery.

What we need now is to bring these trends together and have a pan-European approach to economic integration. Foreign aid can play an important role in helping this trend to succeed.

Global public goods - As pointed out by Kofi Annan, the former Secretary General of the United Nations, "Not only are development, security and human rights all imperative; they also reinforce each other. This relationship has only been strengthened in our era of rapid technological advances, increasing economic interdependence, globalization and dramatic geopolitical change." (in 'In larger freedom: towards development, security and human rights for all', page 5). In a world of interconnected threats and challenges, it is in each country's self interest that all of them are addressed effectively and this can be done through sustained global cooperation among States. In this context, the issue of global public goods needs to be addressed.

Many developing countries need new technologies to address specific needs. There are realistic prospects for developing new vaccines and medicines for malaria, HIV/AIDS, TB and other killer diseases in poor countries. Improved agricultural varieties and cropping systems can increase the food productivity of rainfed agriculture. Accurate environmental monitoring and forecasting can help focus interventions for the greatest positive impact. Many other examples abound for such public goods that, once developed, could be shared broadly to help all countries.

Peacekeeping is another important public good. The last two decades have seen at least several dozen major armed conflicts in different locations, most of them civil wars. Although the number of conflicts has fallen from its peak in the 1990s, the last few years saw a major international escalation of the conflict in Afghanistan, Iraq, etc. Meanwhile, longstanding conflicts continue to rage in Colombia, the Democratic Republic of the Congo (DRC), and Sudan (to name but three). And others are in reconstruction from earlier civil wars, including Bosnia and Herzegovina, Guatemala, and Mozambique. In order to reduce the intensity of conflict as well as maintain the post-conflict stability requires peacekeeping by an international force. The affected countries are in no position to fund these peacekeeping 
activities. So foreign aid is essential in providing for peacekeeping forces and maintaining stability around the globe.

Likewise, health R\&D is limited for diseases affecting the poor, with only 10 percent of global funding used for research into 90 percent of the world's health problems (Global Forum for Health Research 2002). The WHO's Commission on Macroeconomic and Health recommends that annual funding for R\&D on global public goods in health should be increased to $\$ 3$ b by 2007 and $\$ 4$ by 2015 , compared with roughly $\$ 0.3 b$ million annually today (WHO 2001). The situation is similar in other areas of global public goods which are critical to the needs of developing and transition countries.

The relative nature of growth of a country could also be improved through the development of the knowledge economy. International policy dialogue could help global knowledge sharing. This could also be assisted by developing norms and standards for countries in different sectors and then helping to implement them. Implementation of these norms and standards require capacity development in the developing and transition countries.

Global public goods are often overlooked and underprovided in most developing and transition economies, despite their critical role in promoting development as well as the fact that developed countries stand to benefit directly. Two main reasons can be cited for this. First, the cost of coordination among different countries is extremely high, requiring strong regional institutions that do not exist in most parts of the developing world. Second, the attribution of responsibility is a problem. This relates more to the way donors operate. Bilateral and multilateral agencies tend to allocate funds on the basis of individual country performance and needs. This approach doesn't work for global public goods since it is extremely difficult to assign the investment benefit to individual countries. As a result, it is often very difficult to obtain loan guarantees for regional projects from individual countries. To overcome similar problems, regional infrastructure projects in the European Union are justified by their benefits to the entire community and financed from the EU's core budget (comparable mechanisms could be established among developing countries).

\section{Link between normative and operational activities}

"Normative" work implies standard setting, the formulation of policy, the articulation of what people ought to be doing, their rights and obligations, etc. "Operational" work, on the other hand, implies not only the developmental activities leading to the implementation of actual programmes of technical assistance, but also the execution of policy and the application of standards and guidelines. A successful link between these two types of activities is necessary for development assistance to be effective. The adoption of norms and standards in specific areas or sectors often require operational activities for the full implementation in 
practice of the principles they embody. Indeed, technical cooperation is increasingly seen as an essential contribution to the application of standards. At the same time, operational activities contribute to a country's substantive knowledge of issues and can provide essential input to the development of new standards.

Aid for trade stands out as a special case of economic integration. In undertaking trade reform and to participate effectively in the global trading system, poorer countries are faced with a gamut of concerns and issues. For some there will be adjustment costs to preference erosion, and others may face a loss in terms of trade (notably for net food importers). Countries where tariff revenues make up a significant proportion of total fiscal resources may well need to undertake tax reform. Another fundamental issue is that for many developing countries they are ill equipped to take full advantage of new trade opportunities because of significant supply side and human and institutional constraints. Improved market access without the capacity and transportation to sell isn't of much use. Gains from trade liberalization are conditional on an environment that allows the mobility of labour and capital to occur, that facilitates investment in new sectors of activity and also can provide the vulnerable with some assurance that they will be assisted, if necessary.

Seen, in this context, supporting trade adjustment and integration requires a shift towards more efficient transfer/assistance mechanisms with support directed at priority areas defined in national development plans and strategies. Allocation of foreign aid to support trade integration can help gradually to eliminate the current system of discriminatory trade preferences. 


\section{Conclusions}

The current debates on poverty reduction, debt relief and, more broadly, the efficacy of development assistance have shed renewed light on foreign aid. Development assistance is at the heart of a new bipolarism that is evident in both the donor and the recipient countries. On one hand, there is a growing perception in the recipient countries that the donors are not sharing opportunities and wealth in supporting economic growth and fighting poverty in the developing world. On the other hand, public opinion in the donor countries increasingly consider development assistance as nothing more than a way to sustain undemocratic regimes and support unsustainable economic policies.

Questions have also been raised regarding the magnitude of development assistance. Our initial analysis, however, show that once we add to the ODA expenditures, the recent surge in spending for peacekeeping and humanitarian intervention, the picture of the donor countries' commitments changes significantly.

The question that is, therefore, relevant for the debate on the efficacy of development assistance is not so much as an issue of how much, but rather for what. In view of the growing awareness of ODA's inefficiency in achieving intended aims, this paper proposes an alternative approach to development assistance policies - economic integration and subsidiarity provides the conditions necessary for ODA to produce higher rates of economic growth on a sustainable basis. Europe is an excellent case in point, in this context. Europe has in the last decades experienced a number of success wtories in moving out of poverty and onto sustainable economic growth. The secret of success has been the push towards economic integration, and the adoption of economic reforms at the local, national, and regional level conducive to economic growth.

The recipient countries of development assistance have much to learn from the European experience. The need for a political thrust, strategic purpose, institutional support and bold reform initiatives to supplement the receipt of development assistance cannot be overemphasized. Efforts to successfully integrate into the global economic system are also a pre-condition for these countries for better enjoying the fruits of foreign economic assistance. 


\section{References}

Boone, P., "The Impact of Foreign Aid on Savings and Growth," Centre for Economic Performance, Working Paper No. 677, 1994.

Burnside, C. and D. Dollar, "Aid, Policies and Growth," American Economic Review, Vol. 90, No. 4, September 2000, pp. 847-68.

Burnside, C. and D. Dollar, "Aid, Policies, and Growth: Revisiting the Evidence," Policy Research Working Paper No. 3251, Washington, D.C.: The World Bank, 2004.

Clemens, M., S. Redelet and R. Bhavnani, "Counting Chickens When They Hatch: The Short-term Effect of Aid on Growth," Center for Global Development Working Paper No. 44, November 2004.

Collier, P. and A. Hoeffler, "Aid, Policy and Growth in Post-Conflict Societies," Policy Research Working Paper No. 2902, Washington, D.C.: The World Bank, 2002.

Dalgaard, C. and H. Hansen, "On Aid, Growth, and Good Policies," CREDIT Research Paper No. 00/17, Centre for Research in Economic Development and International Trade, University of Nottingham, 2000.

Dalgaard, C. and F. Tarp, "On the Empirics of Foreign Aid and Growth," Economic Journal, Vol. 114, 2004, pp. 191-216.

Dowling, J. and U. Hiemenz, "Aid, Savings, and Growth in the Asian Region," Report No. 3, Economic Office, Asian Development Bank, 1982.

Garonna, P., "What is New about New Europe's View of the Future of Europe," Paper presented at the Krynica Economic Forum, Krynica, Poland, 6-9 September 2006.

Global Forum for Health Reseaerch, Report on Health Research, 2002.

Hansen, H. and F. Tarp, "Aid Effectiveness Disputed," Journal of International Development, Vol. 12, 2000, pp. 375-98. 
Hubner, D., "Competitiveness of the European Economy in a Globalised World", Presentation at the $62^{\text {nd }}$ Annual Sesion of the United Nations Economic Commission for Europe, Geneva, 26 April, 2007.

Isham, J., D. Kaufmann, and L. Pritchett, "Governance and Returns on Investment: An Empirical Ingestigation," World Bank Policy Research Working Paper No. 1550, Washington: World Bank, 1995.

Lensink, R. and H. White, "Are there Negative Returns to Aid?" Journal of Development Studies, Vol. 37(6), 2001, pp. 42-65.

Levine, R. and others, Millions Saved: Proven Success in Global Health, Washington: Center for Global Development, 2004.

Levy, V., "Aid and Growth in Sub-Saharan Africa: The Recent Experience," European Economic Review, Vol 32(9), 1988, pp. 1777-95.

Radelet, S., Challenging Foreign Aid: A Policymaker's Guidetot the Millennium Challenge Account, Washington: Center for Global Development, 2003.

Radelet, Steven, "A Primer on Foreign Aid," Center for Global Development, Working Paper No. 92, July 2006.

Rajan, R. and A. Subramanian, "Aid and Growth, What Does the Cross Country Evidence Really Show?" IMF Working Paper No. 05/127, June 2005.

Sachs, J. et al, "Ending Africa's Poverty Trap," Brookings Papers on Economic Activity 1:2004, pp. 117-240.

Santiso, C. "Improving the Governance of European Foreign Aid: Development Aid as an Element of Foreign Policy," CEPS Working Document No. 189, Centre for European Policy Studies, 2002.

United Nations, In larger freedom: towards development, security and human rights for all' Report of the Secretary General, New York, 2005. 
World Health Organization, Commission on Macroeconomic and Health, Geneva: WHO, 2001. 
Chart 1.

Chart 1: Net ODA in 2005

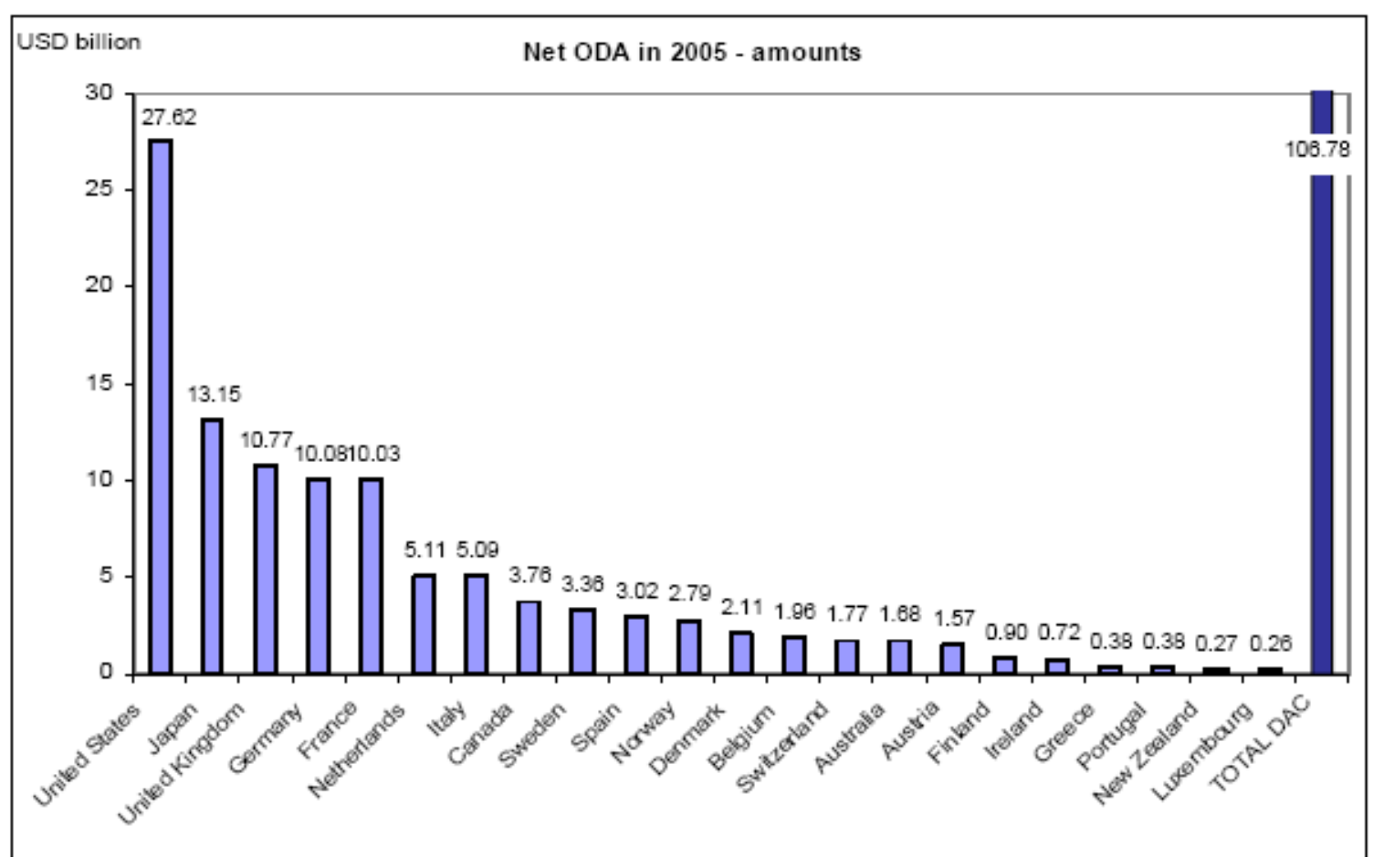

Chart 1: Net ODA in 2005

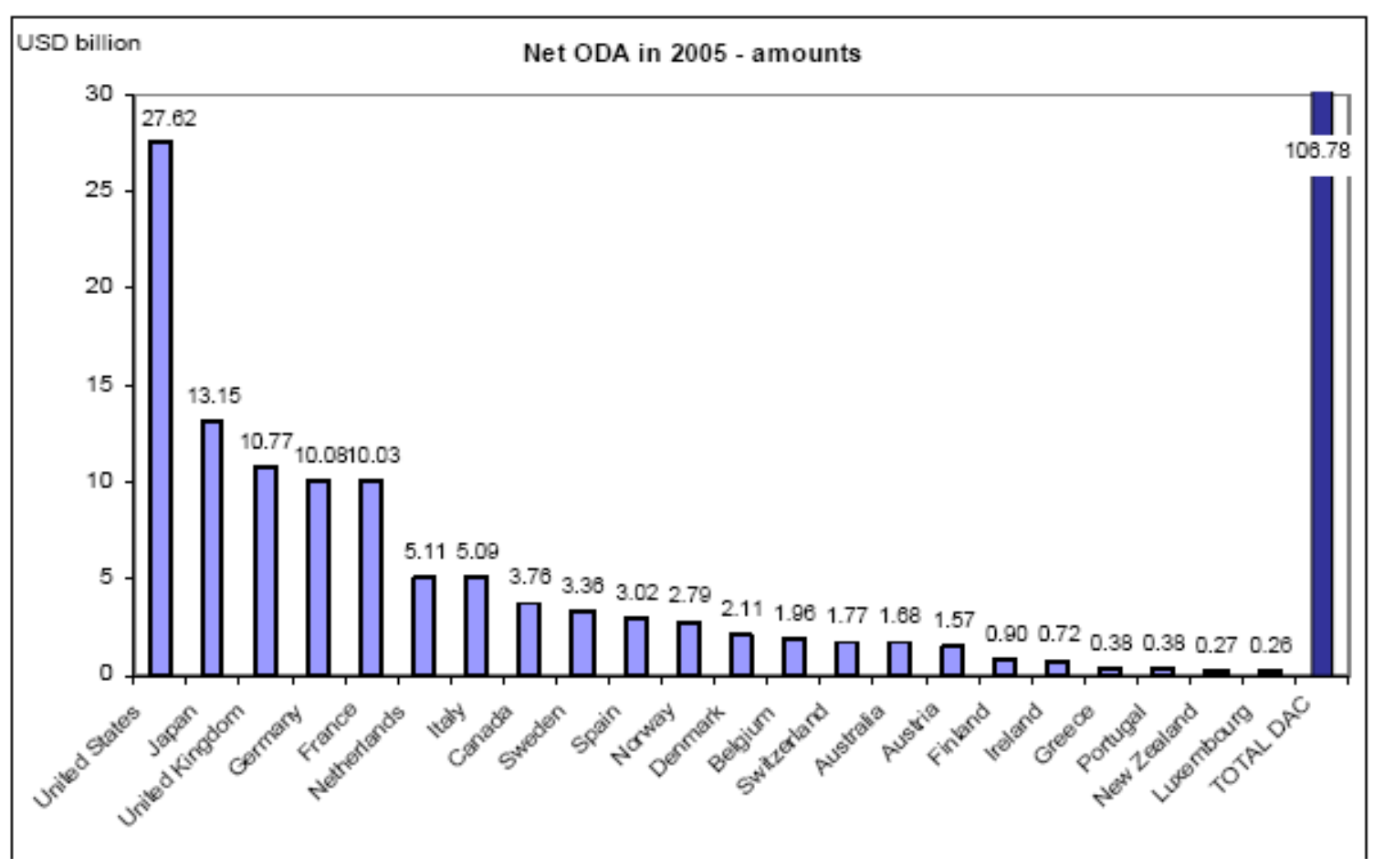


Chart 2.

DAC members' net ODA 1990-2005 and DAC Secretariat simulations of net ODA to 2006 and 2010

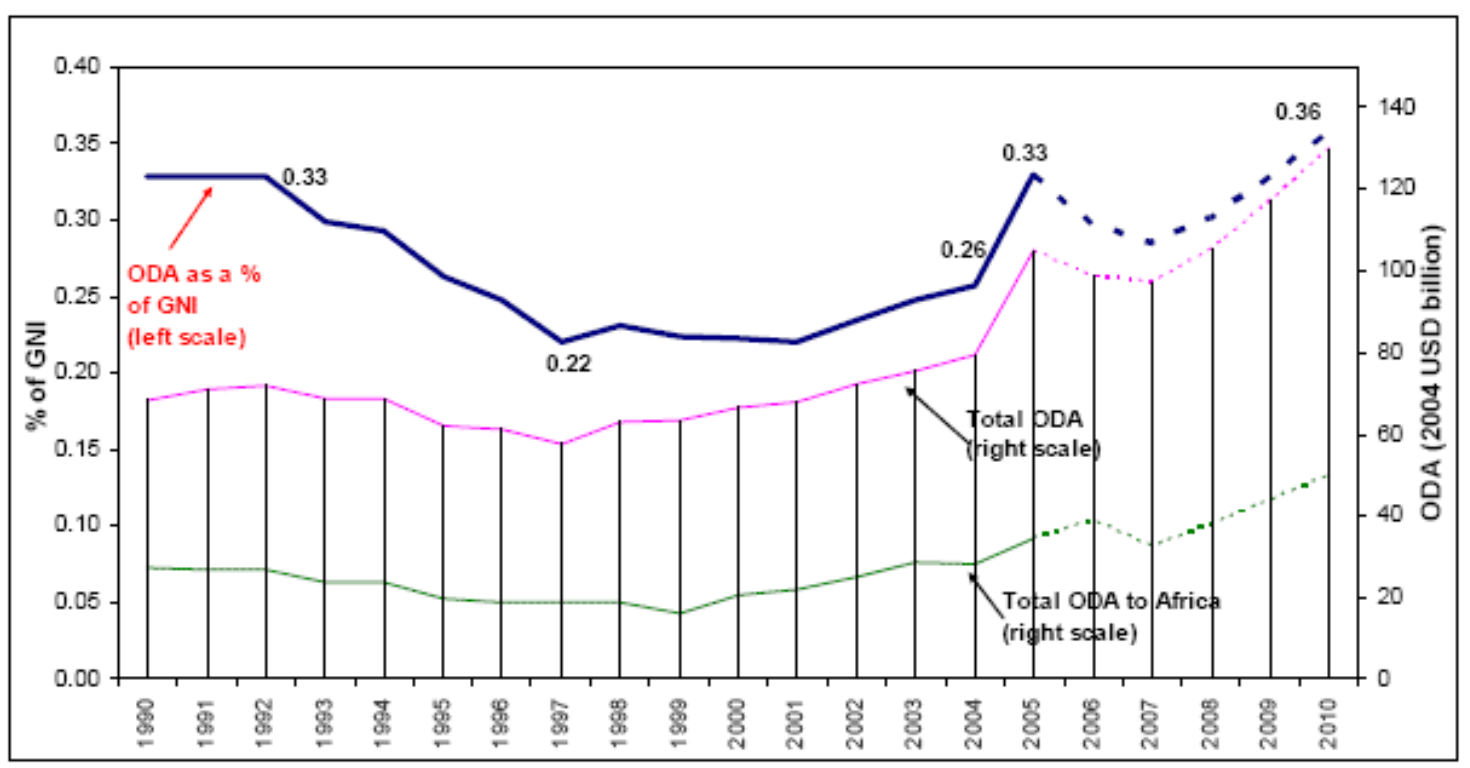


Table 1. Peacekeeping Operations Expenditures 1947-2005 (US\$ million)

\begin{tabular}{|c|c|c|c|c|c|c|c|}
\hline Year & $\begin{array}{c}\text { Total PKO } \\
\text { Expenditures }\end{array}$ & Year & $\begin{array}{c}\text { Total PKO } \\
\text { Expenditures }\end{array}$ & Year & $\begin{array}{c}\text { Total PKO } \\
\text { Expenditures }\end{array}$ & Year & $\begin{array}{c}\text { Total PKO } \\
\text { Expenditures }\end{array}$ \\
\hline 1947 & 0 & 1962 & 126 & 1977 & 153 & 1992 & 1,767 \\
\hline 1948 & 4 & 1963 & 127 & 1978 & 202 & 1993 & 3,059 \\
\hline 1949 & 7 & 1964 & 91 & 1979 & 186 & 1994 & 3,342 \\
\hline 1950 & 7 & 1965 & 45 & 1980 & 141 & 1995 & 3,364 \\
\hline 1951 & 6 & 1966 & 45 & 1981 & 141 & 1996 & 1,405 \\
\hline 1952 & 6 & 1967 & 37 & 1982 & 141 & 1997 & 1,160 \\
\hline 1953 & 6 & 1968 & 24 & 1983 & 141 & 1998 & 995 \\
\hline 1954 & 6 & 1969 & 24 & 1984 & 141 & 1999 & 1,324 \\
\hline 1955 & 6 & 1970 & 24 & 1985 & 141 & 2000 & 2,139 \\
\hline 1956 & 9 & 1971 & 24 & 1986 & 242 & 2001 & 2,700 \\
\hline 1957 & 26 & 1972 & 24 & 1987 & 240 & 2002 & 2,702 \\
\hline 1958 & 30 & 1973 & 37 & 1988 & 266 & 2003 & 2,727 \\
\hline 1959 & 26 & 1974 & 131 & 1989 & 635 & 2004 & 3,645 \\
\hline 1960 & 76 & 1975 & 153 & 1990 & 464 & 2005 & 4,737 \\
\hline 1961 & 126 & 1976 & 153 & 1991 & 490 & 2006 & \\
\hline
\end{tabular}

Source: Global Policy Forum 


\section{Chart 3. Peacekeeping Operations Expenditures 1947-2005}

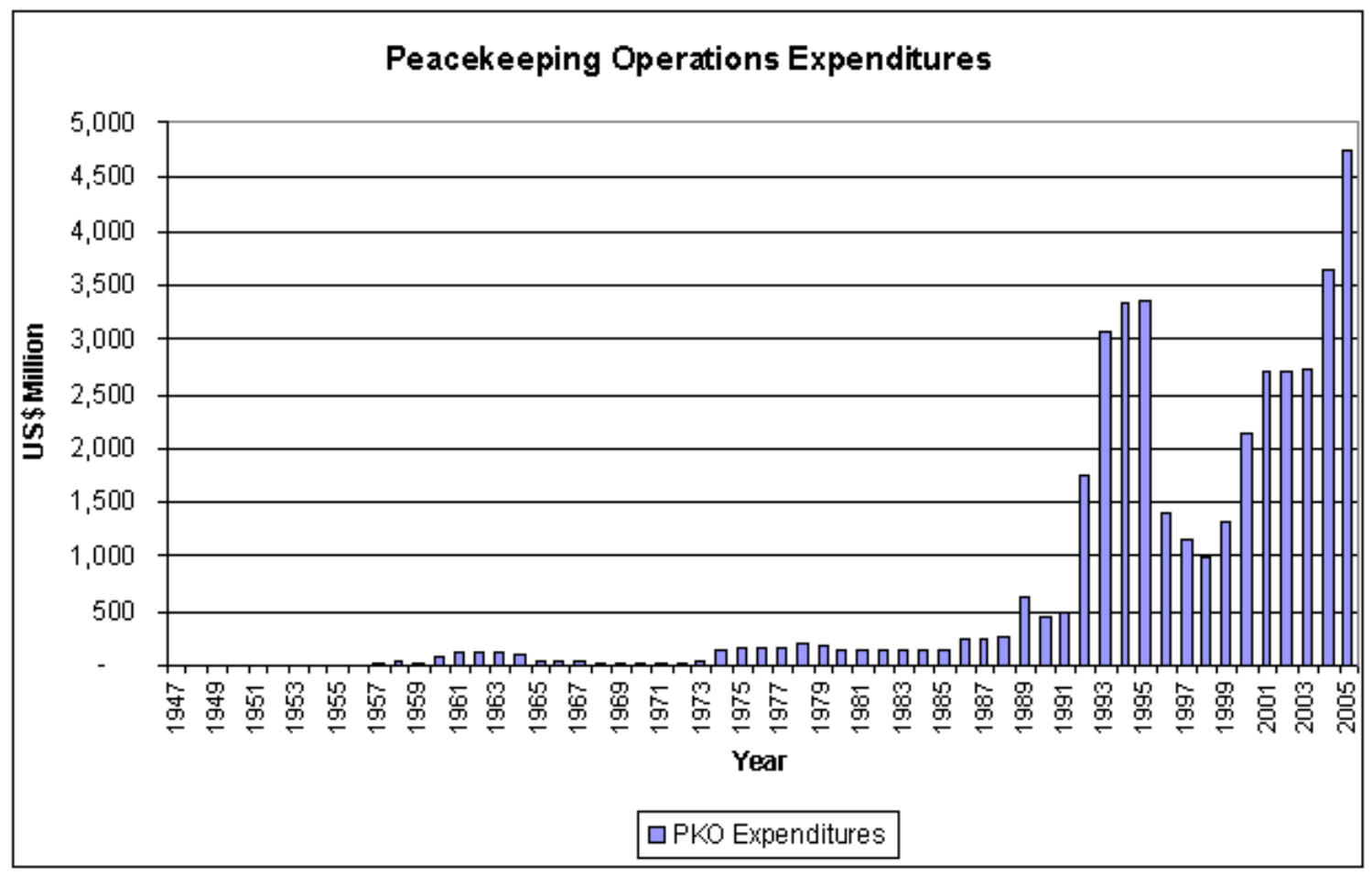

Source: Global Policy Forum 
Table 2. Global Humanitarian Contributions in 2006: Total by Donors

\begin{tabular}{|c|c|c|c|}
\hline Denor & $\begin{array}{l}\text { Funding } \\
\text { USD }\end{array}$ & $\begin{array}{c}\% \text { of Grand } \\
\text { Total }\end{array}$ & $\begin{array}{l}\text { Unoommitied } \\
\text { pledges } \\
\text { USD }\end{array}$ \\
\hline United States & $1,886,756,285$ & $26.2 \%$ & $127,112,46 d$ \\
\hline European Commission (ECHO) & $825,785,845$ & $11.5 \mathrm{~m}$ & $254,541,005$ \\
\hline Carry-over (donoss not speciñed) & $526,476,362$ & $7.3 x$ & 0 \\
\hline United Kingdom & $470,644,850$ & $6.5 \%$ & $7,597,949$ \\
\hline Sweden & $384,525,469$ & $5.1 \%$ & $12,480,195$ \\
\hline Noway & $354,363,804$ & 497 & $3,097,718$ \\
\hline Netheriands & $338,770,353$ & $4.7 \%$ & $14,737,414$ \\
\hline Swizerland & $264,378,348$ & $3.7 \%$ & $6,946,846$ \\
\hline Canada & $242,396,908$ & $3.4 \%$ & $46,246,504$ \\
\hline Denniark & $180,507,690$ & $26 \%$ & $5,499,041$ \\
\hline Gemany & $184,457,657$ & $2.6 \%$ & $19,056,089$ \\
\hline Allocations of uneamarked funds by UN & $173,201,297$ & $2.4 \%$ & 200,000 \\
\hline Japan & $168,381,372$ & $2.3 \%$ & $16,672,027$ \\
\hline Private (individuals 8 organisations) & $140,603,521$ & $21 \%$ & 725,222 \\
\hline Ireland & $134,017,184$ & $1.3 \%$ & $a$ \\
\hline Saudi Arabia & $131,075,327$ & $1.8 \%$ & $10,000,000$ \\
\hline France & $98,709,595$ & $1.4 \%$ & $2,208,080$ \\
\hline Australie & $85,290,400$ & $1.2 \%$ & $2,262,617$ \\
\hline European Commission & $79,096,409$ & $1.1 \mathrm{x}$ & 0 \\
\hline taly & $76,044,022$ & $1.1 \%$ & $7,300,725$ \\
\hline Finland & $72,834,819$ & $1.0 \%$ & $14,382,842$ \\
\hline Belghum & $84,950,935$ & $0.9 \%$ & $79,044,98$ \\
\hline Spain & $59,638,184$ & $0.8 \%$ & $\$ 5,641,406$ \\
\hline Sudan & $36,220,000$ & $0.5 \%$ & $\varphi$ \\
\hline United Arab Eminates & $31,773,746$ & $0.4 \%$ & 15,000 \\
\hline Others & $192,990,410$ & $27 \%$ & $390,202,793$ \\
\hline Grand Total: & $7,200,379,001$ & $100 \%$ & $975,786,725$ \\
\hline
\end{tabular}

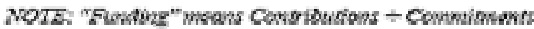

Note : Compiled by OCHA on the basis of information provided by donors and appealing agencies.

Source:

http://www.reliefweb.int/fts 
Chart 4. Global Humanitarian Contributions in 2006: Total by Donors

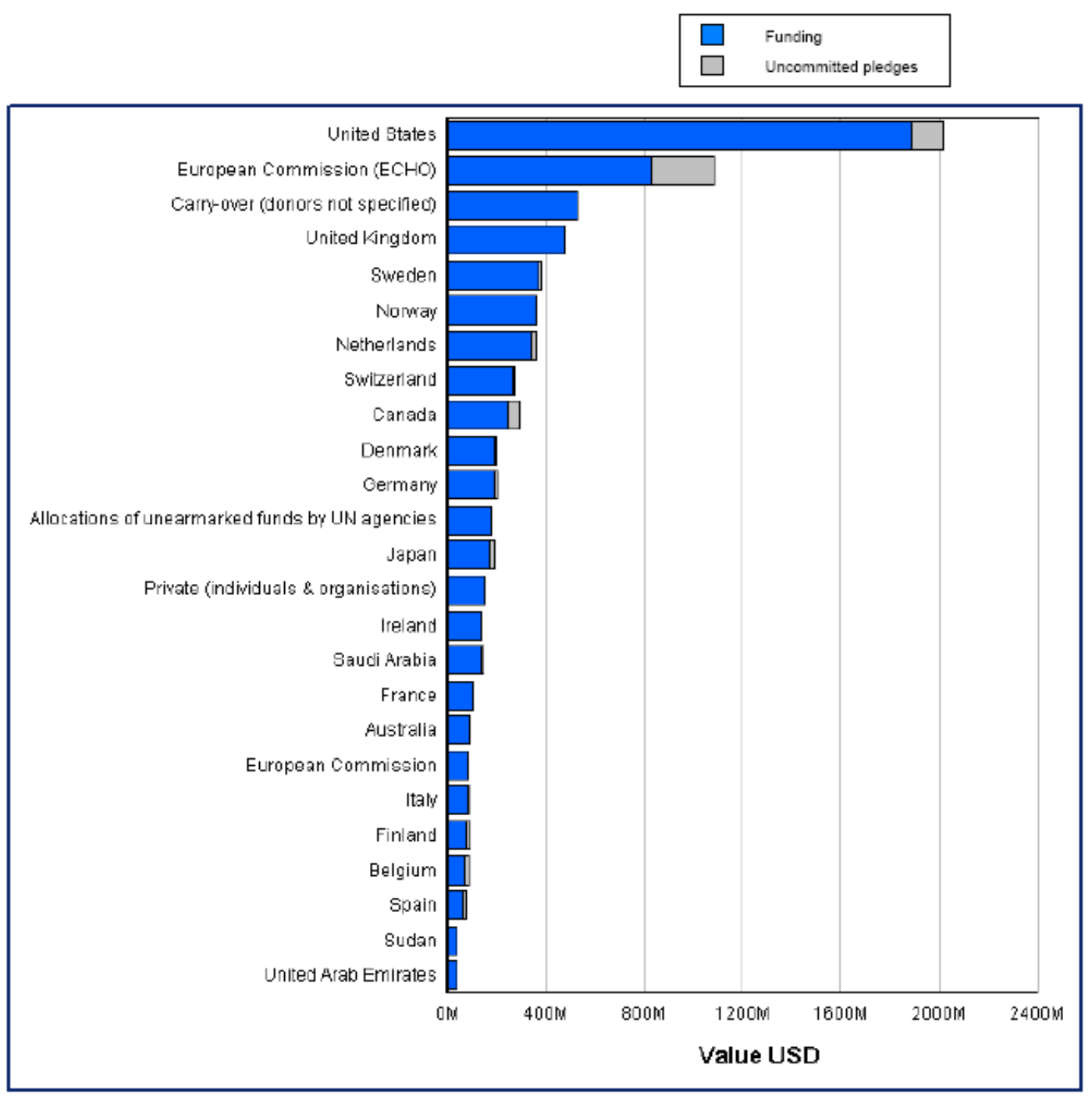

Source: http://www.reliefweb.int/fts 
Table 3. Global Humanitarian Contribution in Recent Years : Total by Donors

$\begin{array}{cc}\text { Year } & \text { Funding in US\$ ('000) } \\ 2006 & \$ 7,201,717 \\ 2005 & 13,140,287 \\ 2004 & 4,732,381 \\ 2003 & 7,531,467 \\ 2002 & 5,116,713 \\ 2001 & 3,798,718 \\ 2000 & 1,772,120\end{array}$

Note: Funding means Contributions plus Commitments.

Compiled by OCHA based on the information provided by donors and appealing agencies.

Source: http://www.reliefweb.int/fts 